\title{
Evaluation of Linearity Air Kerma Applied to the IEC 60601-2-45 Standard in Mammographic X-ray
}

\author{
Dong-Hee Hong ${ }^{1.2}$, Hong-Ryang Jung ${ }^{2}$, Cheong-Hwan Lim², \\ Beom-Hee Han ${ }^{3.4}$, Sang-Hyun $\mathrm{Han}^{3}$, Sang-Ho Lee ${ }^{3}$, \\ Eun-Hee $\mathrm{Mo}^{4}$, Ki-Jung $\mathrm{Kim}^{2.5}$, Mi-Hwa Lee ${ }^{2.6}$, In-Gyu You ${ }^{2.7}$
}

Dept of Health Care, Hanseo University ${ }^{1}$, Dept. of Radiological Science, Far east University ${ }^{2}$, Dept. of Radiological Science, Seonam University ${ }^{3}$, Dept. of Radiation Science \& Technology, Chonbuk National University ${ }^{4}$, Dept. of Dignostic Radiology, Konkook University Hospital ${ }^{5}$, Dept. of Dignostic Radiology, Kyunghee University Hospital ${ }^{6}$, Dept. of Dignostic Radiology, Hallym University Hospital ${ }^{7}$ Dept. of Dignostic Radiology, Wonkwang University Hospital ${ }^{8}$

\section{유방촬영용 X선 진단장치에서 \\ IEC 60601-2-45 표준규격을 적용한 직선성 평가}

홍동희 ${ }^{1,2}$, 정홍량 ${ }^{2}$, 임청환 ${ }^{2}$, 한범희 $^{3.4}$, 한상현 ${ }^{3}$, 이상호 ${ }^{3}$, 모은희 ${ }^{4,}$ 김기정 ${ }^{2,5}$, 이미화 ${ }^{2,6}$, 유인규 ${ }^{2,7}$

한서대학교 보건의료학과 ${ }^{1}$, 극동대학교 방사선학과 ${ }^{2}$, 서남대학교 방사선학과 ${ }^{3}$, 전북대학교 방사선과학기술학과 ${ }^{4}$, 건국대학교 영상의학과 ${ }^{5}$, 강동경희대학교병원 영상의학과 ${ }^{6}$, 한림대학교병원 영상의학과 ${ }^{7}$, 원광대학교병원 영상의학과 ${ }^{8}$

\begin{abstract}
The quality control items of mammography devices in South Korea do not include the linearity, which is required by international standards. The linearity is a requirement for the adjustment of radiation dose and radiation quality. This study tested the linearity, which was suitable for the IEC 60601-2-45 standard, of the 5 mammography devices. All showed adequate results. Consistent measurement management is required for more developed quality control in the future.
\end{abstract}

Key Words : IEC 60601-2-45 Standard, Linearity, Mammography device, Quality control

요 약 현재 우리나라 유방촬영장치의 정도관리 항목에는 국제규격에서 원하는 직선성이 빠져있다. 직선성은 방사선량 및 방사선질의 조정을 위한 요구사항이다. 본 연구에서는 유방촬영장치 5대를 대상으로 IEC 60601-2-45 규격에 맞는 직선성을 시험한 결과 모두 적합한 결과를 보였으며 앞으로 좀 더 발전된 정도관리 를 위해서는 지속적인 측정관리가 필요하다.

주제어 : IEC 60601-2-54 표준규격, 직선성, 유방촬영장치, 정도관리

\footnotetext{
Received 4 February 2014, Revised 5 March 2014 Accepted 20 March 2014

Corresponding Author: Hong-Ryang Jung(Dept. of Health Care Hanseo)

Email: hrjung@hanseo.ac.kr
}

ISSN: $1738-1916$
(C) The Society of Digital Policy \& Management. All rights reserved. This is an open-access article distributed under the terms of the Creative Commons Attribution Non-Commercial License (http://creativecommons.otg/licenses/by-nc/3.0), which permits unrestricted non-commercial use, distribution, and reproduction in any medium, provided the original work is properly cited. 


\section{Introduction}

International institutions have developed quality and performance management programs for the installation and use of radiation generators used in disease diagnosis. South Korea has had limited test conditions or test methods according to the Ministry of Health and Welfare. Pre-quality management and postperformance management were realized with the "regulation for safety management of diagnosis radiation generators," which was legislated in 1995 by the Korea Food and Drug Administration [1].

The radiation generators used in medical centers have routine inspections every 3 years according to the regulations for safety management, and are strictly regulated with the suspension of use for inconsistencies [2]. Therefore, performance management and quality management of generators should be accomplished in accordance with the regulations for safety management of The Ministry of Health and Welfare law for radiation generators [3][4][5]. Routine inspection is required with quality control items. However, the quality control items used in Korea have a slight difference compared to items used for international standards.

IEX 60601-2-45 has particular requirements for the safety of mammographic X-ray equipment and mammographic stereotactic devices, and to evaluate the linearity of air kerma over the intervals of limited loading conditions among normal requirements for radiation levels and radiation quality controls [6][7]. This linearity not only helps to control important X-ray levels for both patients and the quality of images, but helps to show the degree of character reproduction sequentially, even in long-term use [8].

The IEC standard is valid for enforcing the quality management of devices, since it uses an internationally certified test method and items. However, inspection agencies enforcing quality management in Korea only enforce it partially.
Therefore, this research proposes a direction of improvement in quality management inspection for future mammographic devices that measure and comparably evaluate the linearity from evaluation items of mammographic diagnosis devices, and evaluates the performance evaluation from post-management items and uses its data.

\section{Materials and Methods}

\subsection{Materials}

Five $\mathrm{CR}$ devices and $\mathrm{DR}$ devices were targeted, and a Raysafe Xi dosimeter was used to measure the air kerma and linearity of mammographic generators according to IEC 60601-2-45 (Fig 1).

The mammographic $\mathrm{X}$-ray equipment used is as follows:

- LORAD AFFINITY (Hologic inc.)

- LORAD VARIAN (Hologic inc.)

- NOVATION MAMMOMAT (Siemens inc.)

- ALPHA ST MGF-101 (GE inc.)

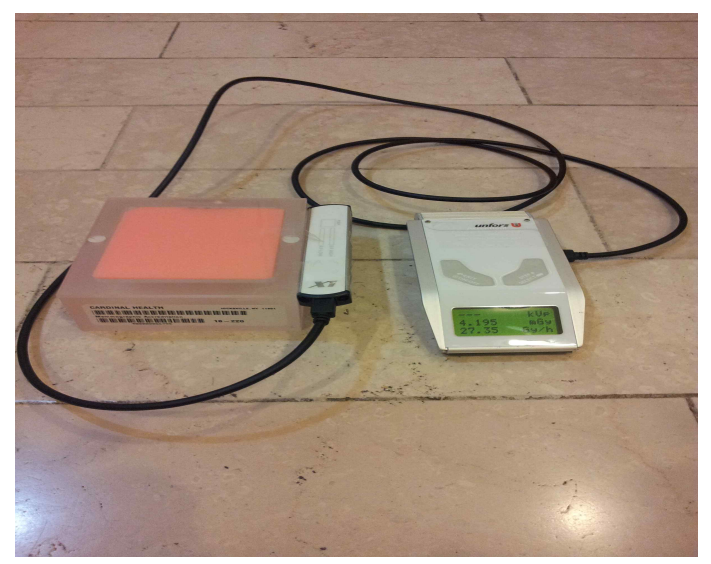

[Fig. 1] Measurement tools

\subsection{Methods of linearity}

The measurement method used 10 loads for each selected mAs set-up and measuring air kerma in a 
fixed area at over $40 \mathrm{~mm}$ from a patient (Fig 2). The average of air kerma from each of ten measurements was calculated (1), and it was determined whether the value matches with the equation.

$$
\left|\frac{\overline{K_{1}}}{Q_{1}}-\frac{\overline{K_{2}}}{Q_{2}}\right| \leq 0.2 \frac{\overline{\bar{K}_{1}}+\frac{\overline{K_{2}}}{Q_{2}}}{2}
$$

The variables of air kerma measurement values should have an accuracy of 0.2 or higher for changes of the selected mAs from all mAs linearly.

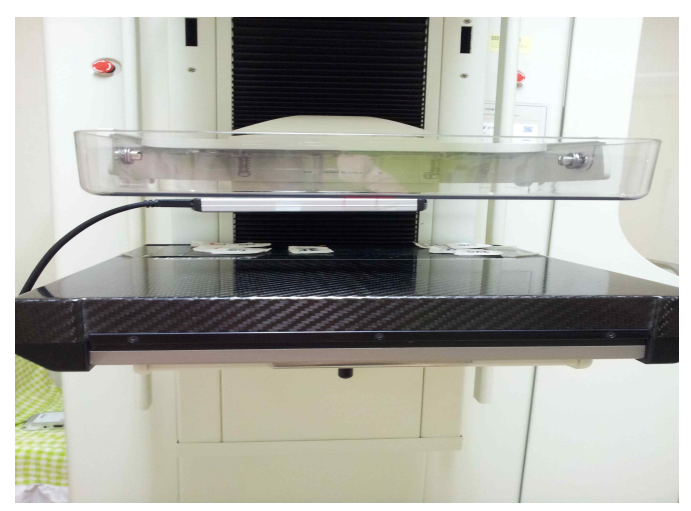

[Fig. 2] Air kerma measurements

The measurement of suitability was enforced at 30 $\mathrm{kvp}$, and the mAs setup for testing of the low value of the first pair corresponded to the minimum mAs setup. The set point proportion of the selected mAs of each pair should be close to 2 if possible, but must not exceed 2. The high value of $\mathrm{mAs}$ setup for each pair to be measured should be low for the next pair of $\mathrm{mAs}$ setups. The value of the maximum condition should correspond with the maximum mAs setup, and the low value should be half for the next value while corresponding to the half or maximum mAs setup.

\section{Results and Discussion}

\subsection{Results}

Five mammographic $\mathrm{X}$-ray devices were applied to
IEC 60601-2-45, and the linearity of air kerma over the interval of limited load conditions was evaluated (Tables 1-5).

$<$ Table $1>$ Linearity of first equipment

\begin{tabular}{|c|c|c|c|c|c|c|}
\hline $\begin{array}{c}\text { Equipm } \\
\text { ent }\end{array}$ & KV & $\mathrm{mAs}$ & $\begin{array}{l}\text { Mean } \\
\text { (mGy) }\end{array}$ & $\begin{array}{l}\text { mGy } \\
/ \mathrm{mAs}\end{array}$ & Linearity & $\begin{array}{c}\text { Evalu } \\
\text { ation }\end{array}$ \\
\hline \multirow[t]{10}{*}{$\begin{array}{l}\text { No.1 } \\
\end{array}$} & 30 & 4 & 0.72 & 0.180 & $0.004 \leq 0.036$ & conformity \\
\hline & 30 & 6 & 1.10 & 0.184 & $0.002 \leq 0.037$ & conformity \\
\hline & 30 & 12 & 2.23 & 0.186 & $0.001 \leq 0.037$ & conformity \\
\hline & 30 & 20 & 3.74 & 0.187 & $0.000 \leq 0.037$ & conformity \\
\hline & 30 & 40 & 7.50 & 0.188 & $0.000 \leq 0.037$ & conformity \\
\hline & 30 & 80 & 15.05 & 0.188 & $0.000 \leq 0.038$ & conformity \\
\hline & 30 & 150 & 28.16 & 0.188 & $0.001 \leq 0.037$ & conformity \\
\hline & 30 & 300 & 37.81 & 0.189 & & $*$ \\
\hline & 30 & 200 & 56.44 & 0.188 & $0.000 \leq 0.037$ & conformity \\
\hline & 30 & 400 & 75.33 & 0.188 & & $*$ \\
\hline
\end{tabular}

* Blank for the maximum mAs setup and corresponded value setup

$<$ Table $2>$ Linearity of second equipment

\begin{tabular}{cccccc}
\hline $\begin{array}{c}\text { Equipm } \\
\text { ent }\end{array}$ & KV mAs & $\begin{array}{c}\text { Mean } \\
\text { (mGy) }\end{array}$ & $\begin{array}{c}\text { mGy } \\
\text { /mAs }\end{array}$ & Linearity & $\begin{array}{c}\text { Evalu } \\
\text { ation }\end{array}$ \\
\hline \hline No.2 & 30 & 2 & 0.35 & 0.173 & $0.000 \leq 0.035$ conformity \\
\hline 30 & 4 & 0.69 & 0.173 & $0.002 \leq 0.035$ conformity \\
\hline 30 & 8 & 1.40 & 0.175 & $0.000 \leq 0.035$ conformity \\
\hline 30 & 16 & 2.80 & 0.175 & $0.001 \leq 0.035$ conformity \\
\hline 30 & 32 & 5.62 & 0.176 & $0.001 \leq 0.035$ conformity \\
\hline 30 & 63 & 11.12 & 0.176 & $0.001 \leq 0.035$ conformity \\
\hline 30 & 125 & 22.13 & 0.177 & $0.000 \leq 0.035$ conformity \\
\hline 30 & 250 & 44.36 & 0.177 & $0.000 \leq 0.036$ conformity \\
\hline 30 & 500 & 88.86 & 0.178 & \\
\hline
\end{tabular}

* Blank for the maximum mAs setup and corresponded value setup

$<$ Table $3>$ Linearity of third equipment

\begin{tabular}{|c|c|c|c|c|c|c|}
\hline $\begin{array}{c}\text { Equipm } \\
\text { ent }\end{array}$ & KV & $\mathrm{mAs}$ & $\begin{array}{l}\text { Mean } \\
\text { (mGy) }\end{array}$ & $\begin{array}{l}\text { mGy } \\
/ \mathrm{mAs}\end{array}$ & Linearity & $\begin{array}{c}\text { Evalu } \\
\text { ation }\end{array}$ \\
\hline \multirow[t]{9}{*}{ No.3 } & 30 & 4 & 0.58 & 0.144 & $0.014 \leq 0.030$ & conformity \\
\hline & 30 & 8 & 1.26 & 0.158 & $0.016 \leq 0.030$ & conformity \\
\hline & 30 & 16 & 2.28 & 0.142 & $0.000 \leq 0.028$ & conformity \\
\hline & 30 & 30 & 4.26 & 0.142 & $0.001 \leq 0.028$ & conformity \\
\hline & 30 & 60 & 8.46 & 0.141 & $0.006 \leq 0.029$ & conformity \\
\hline & 30 & 120 & 17.70 & 0.148 & $0.006 \leq 0.029$ & conformity \\
\hline & 30 & 240 & 33.88 & 0.141 & & * \\
\hline & 30 & 250 & 35.87 & 0.143 & $0.016 \leq 0.027$ & conformity \\
\hline & 30 & 500 & 63.61 & 0.127 & & \\
\hline
\end{tabular}

* Blank for the maximum mAs setup and corresponded value setup 
$<$ Table $4>$ Linearity of fourth equipment

\begin{tabular}{ccccccc}
\hline $\begin{array}{c}\text { Equipm } \\
\text { ent }\end{array}$ & KV & mAs & $\begin{array}{c}\text { Mean } \\
\text { (mGy) }\end{array}$ & $\begin{array}{c}\text { mGy } \\
\text { /mAs }\end{array}$ & Linearity & $\begin{array}{c}\text { Evalu } \\
\text { ation }\end{array}$ \\
\hline \hline No.4 & 30 & 4 & 0.55 & 0.138 & $0.007 \leq 0.028$ conformity \\
\hline & 30 & 6 & 0.87 & 0.145 & $0.003 \leq 0.029$ conformity \\
\hline 30 & 12 & 1.78 & 0.148 & $0.001 \leq 0.030$ conformity \\
\hline 30 & 20 & 2.97 & 0.149 & $0.002 \leq 0.030$ conformity \\
\hline 30 & 40 & 6.02 & 0.150 & $0.001 \leq 0.030$ conformity \\
\hline 30 & 80 & 12.15 & 0.152 & $0.000 \leq 0.030$ conformity \\
\hline 30 & 150 & 22.77 & 0.152 & $0.001 \leq 0.030$ conformity \\
\hline 30 & 300 & 45.72 & 0.152 & $*$ \\
\hline 30 & 200 & 31.40 & 0.157 & $0.004 \leq 0.031$ conformity \\
\hline * Blank for the maximum mAs setup and corresponded value \\
setup & 400 & 61.01 & 0.153 &
\end{tabular}

$<$ Table $5>$ Linearity of fifth equipment

\begin{tabular}{ccccccc}
\hline $\begin{array}{c}\text { Equipm } \\
\text { ent }\end{array}$ & KV & mAs & $\begin{array}{c}\text { Mean } \\
\text { (mGy) }\end{array}$ & $\begin{array}{c}\text { mGy } \\
\text { /mAs }\end{array}$ & Linearity & $\begin{array}{c}\text { Evalu } \\
\text { ation }\end{array}$ \\
\hline \hline No.5 & 30 & 3 & 0.54 & 0.181 & $0.009 \leq 0.035$ conformity \\
\hline 30 & 6 & 1.04 & 0.173 & $0.028 \leq 0.037$ conformity \\
\hline 30 & 12 & 2.41 & 0.201 & $0.036 \leq 0.037$ conformity \\
\hline 30 & 24 & 3.97 & 0.165 & $0.001 \leq 0.033$ conformity \\
\hline 30 & 47.5 & 7.82 & 0.165 & $0.001 \leq 0.033$ conformity \\
\hline 30 & 95 & 15.55 & 0.164 & $0.033 \leq 0.036$ conformity \\
\hline 30 & 190 & 37.40 & 0.197 & $0.032 \leq 0.036$ conformity \\
\hline 30 & 375 & 61.69 & 0.165 & $*$ \\
\hline 30 & 260 & 42.35 & 0.163 & $0.000 \leq 0.033$ conformity \\
\hline 30 & 500 & 81.46 & 0.163 & \\
\hline
\end{tabular}

* Blank for the maximum mAs setup and corresponded value setup

All five devices showed appropriate values for the requirements of international standard radiation levels and radiation qualities.

\section{Conclusions and discussion}

The quality management for diagnosis $\mathrm{X}$-ray generators includes acceptance tests and development tests for manufacturing quality management, and consistency tests for user quality management. The acceptance test is performed for suitability of a device for the specifications when a user and manufacturer adopt a device. The development test is performed to verify the performance conditions of equipment on an ordinary day [9].

The development tests in Korea are performed regularly, from every 3 months to every 3 years, but items have large differences when compared to IEC standards. Post-management for linearity is not done after equipment installation, since the linearity directly related to images is excluded.

The IEC improves international understandings by promoting international cooperation on issues and related matters for standardization, such as the observance confirmation of specifications for electric and electronic fields. There is a goal of reflecting the IEC standard form in the international standards of each country by advising with publications [9]. South Korea has announced IEC advice items by KATS in 1999 [10].

In recent research on the quality management conditions of mammographic devices, DoWan Kim (2010) showed that the inconsistency of devices younger than 10 years old was about $1.7 \%$, but the inconsistency of time-worn devices for about 10 years was very high at about 5.6\%[11], in his research on quality management condition comprehension and the future quality management plan of mammographic devices. In addition, advanced research on the performance of devices showed that the performance of devices decreased in smaller hospitals and that time-worn devices need to have inspections more often. Advice was given to perform the overall inspections in the period designated by the manufacturer [12].

According to this research, all linearity was suitable from the results measured for 5 devices of $\mathrm{CR}$ and DR mammographic devices. However, these results are considered not to be suitable for the radiation quality requirements of mammographic devices in the entire nation. Therefore, more improved equipment management is needed by including the linearity in quality management items in the future. In addition, plans to apply after modification and supplementation 
to the nation in 10-year standards need to be established, since the method of applying current linearity measurement to IEC standards concerns the damage of the device for 10 loads per mAs.

\section{References}

[1] Jung-min kim, "Diagnostic x-ray equipment to keep the performance management method" Korea Food \& Drug Administration, Radiation Health Newletter, vol. 19, no.1, pp.15, 2012

[2] In-Kyu You, Chung-hwan lim, Sang-Ho Lee, Man-ku lee, "”, Journal of the Korean Radiological Society, vol.6, no.6, pp.447-454, 2012

[3] Ministry of Health and Welfare, No.186. Radiation generator rules regarding the safety of. 2001.

[4] Ministry of Health and Welfare, No.234. Radiation generator rules regarding the safety of. 2003

[5] Ministry of Health and Welfare, No.349. Radiation generator rules regarding the safety of. 2006.

[6] IEC International Organization, http://www.iec.ch

[7] Medical electrical equipment - Part 2-45: Particular requirements for basic safety and essential performance of mammographic X-ray equipment and mammomagraphic stereotactic devices

[8] Yun, Jeong-Seop; Kim, Chun-Sik; Go, Sin-Gwan, "Medical X-ray equipment on the management of the maintenance and performance review", *Journal of radiological science and technoligy, vol.15, no.1, pp.25-26, 1992.

[9] Bum-Hee Han, Jong-Il Kim, Sang-Ho Lee, Sang-Hyeon Han, In-Kyu You, "Consistent Comparison for The Linearity Air Kerma of IEC Standards and Commercial Load in Diagnosing DR Generators",

[10] Ministry of Commerce, Industry and Energy, Korean Agency for Technology and Standards, http://standard.ats.go.kr

[11] Do-Wan Kim, "”, Korea university Graduate School of Biomedical Sciences, 's, 2010

[12] Joo-Hoon Park, In-Cheol Im, Kyeong-Rae Dong,
Sae-Sick Kang, "”, The Journal of the Korean Association for Radiation Protection,vol.34 no.1, pp.31-36, 2009.

홍 동 희(Hong. Dong Hee)

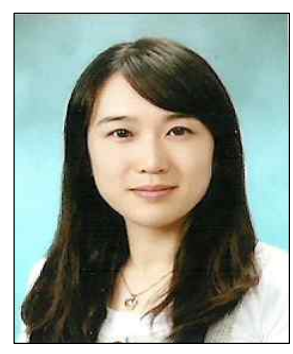

2005년 8월 : 한서대학교 방사선학 과(방사선학석사)

- 2013년 3월 : 한서대학교 보건의료 학과(박사과정)

- 2011년 9월-2014년 2월 : 서남대학 교 방사선학과 교수

-2014년 3월 현재 : 극동대학교 방사선학과 교수

· 관심분야 : 방사선학, 초음파영상

·E-Mail : hansound2@hanmail.net

정 홍 량(Jung. Hong Ryang)

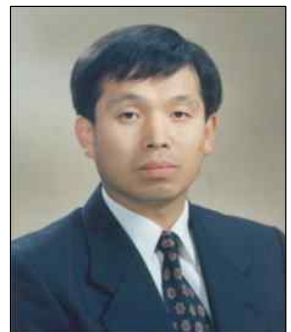

- 1995년 2월 : 단국대학교 행정대학 원 보건행정학과(보건학석사)

- 2004년 8월 : 순천향대학교 환경보 건학과(보건학박사)

- 1999년 3월 현재 : 한서대학교 방사선학과 교수

- 관심분야 : 방사선학, 보건역학

·E-Mail : rjung@hanseo.ac.kr

임 청 환(Lim. Cheong Hwan)

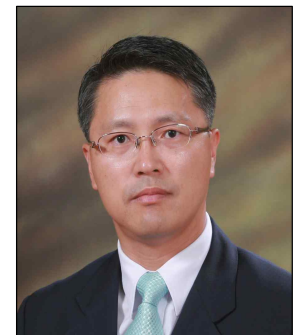

- 1997년 8월 : 단국대학교 행정대학 원 보건행정학과(보건학석사)

- 2005년 2월 : 경원대학교 의료경영 학과(보건학박사)

- 2001년 3월 현재 : 한서대학교 방사선학과 교수

- 관심분야 : 방사선학, 영상정보학

•E-Mail : LCH116@hanseo.ac.kr

한 범 희(Han. Beom Hee)

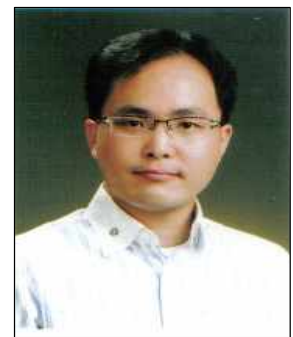

- 2009년 2월 : 한서대학교 방사선학 과(방사선학석사)

- 2011년 2월 : 전북대학교 방사선과 학기술학과(박사수료)

- 2010년 3월 현재 : 서남대학교 방사선학과 교수

- 관심분야 : 방사선물리, 방사선방호

·E-Mail :raphael121215@seonamac.kr 
한 상 현(Han. Sang Hyun)

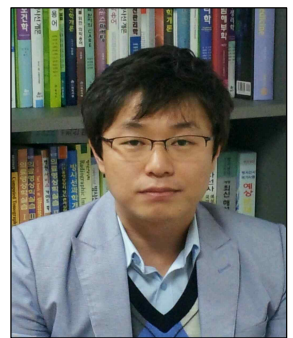

- 2008년 2월 : 건양대학교 보건대학 원(보건학석사)

- 2012년 3월 : 충북대학교 의용생체 공학과(박사과정)

- 2011년 3월 현재 : 서남대학교 방사선학과 교수

- 관심분야 : 핵의학, 보건학

•E-Mail：luck2han@hanmail.net

이 상 호(Lee. Sang Ho)

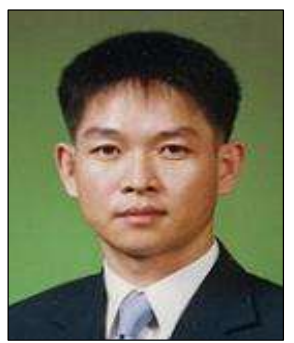

-2009년 8월 : 한서대학교 방사선학 과(방사선학석사)

- 2012년 3월 : 원광대학교 화학과 (이 학박사)

·2010년 8월 현재 : 서남대학교 방 사선학과 교수

· 관심분야 : 방사선학, 보건의료

·E-Mail : ho8350@hanmail.net

모 은 희(Mo. Eun Hee)

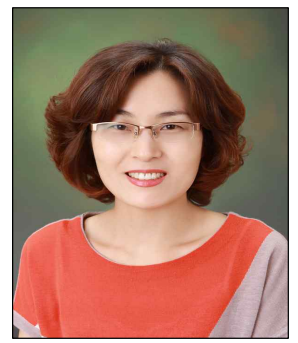

-2009년 8월 : 한서대학교 방사선학 과(방사선학석사)

- 2013년 8월 : 전북대학교 방사선과 학기술학과(이학박사)

- 1995년 1월 현재 : 원광대학교병 원 영상의학과

- 관심분야 : 방사선치료학, 초음파

·E-Mail : mo0428@hanmail.net

김 기 정(Kim. Ki Jeong)

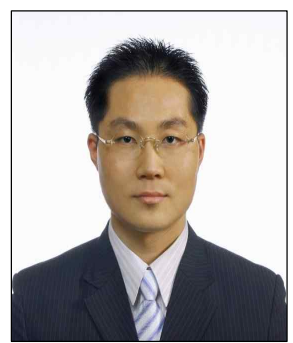

- 2011년 8월 : 한서대학교 방사선학 과(방사선학석사)

- 2013년 2월 현재 : 한서대학교 보건의료학과(박사과정)

- 2001년 6월 현재 : 건국대학교병 원 영상의학과

- 관심분야 : 방사선학, 보건교육

·E-Mail : raidline@kuh.ac.kr
이 미 화(Lee Mi Hwa)

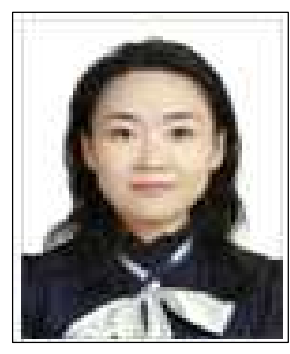

- 2011년 2월 : 연세대학교 보건대학 원 역학통계학과(보건학석사)

- 2013년 2월 현재 : 한서대학교 보 건의료학과(박사과정)

- 2006년 2월 현재 : 강동경희대학 교병원 영상의학과

- 관심분야 : 방사선학, 통계학, 보건 교육

•E-Mail : riqnrd1113@hanmail.net

유 인 규(You. In Gyu)

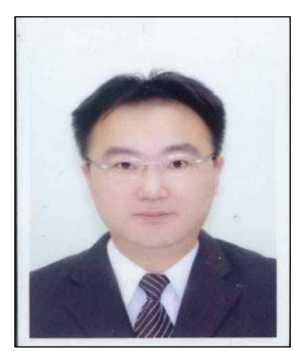

- 2012년 2월 : 한서대학교 방사선학 과(방사선학석사)

- 2012년 2월 현재 : 한서대학교 보건의료학과(박사과정)

- 2011년 3월 현재 : 한서대학교 방사선학과 외래교수

- 관심분야 : 방사선학, 보건정책

·E-Mail : semicoma72@daumnet 